\title{
DYNAMICS OF THE DEVELOPMENT OF THE PHYSICAL ABILITY OF PUPILS OF PRIMARY SCHOOL AGE
}

\author{
Marina Petrova \& Milena Tarnichkova \\ National Sports Academy "Vassil Levski", Sofia, Bulgaria
}

\begin{abstract}
This article presents data from a national scientific project of the National Sports Academy "V. Levski "and the Ministry of Education and Science to study the physical capability of students from secondary schools in the Republic of Bulgaria. Our aim is to establish the initial level of physical qualities of pupils at primary schools. In order to achieve the aim, we set the following tasks: To conduct a testing of the pupils at primary schools; To process and analyze the obtained results; To create exemplary methods for improvement of the testing results. In October 2018, we tested 83 pupils from $1^{\text {st }}$ to $4^{\text {th }}$ grade, aged between 7 and 10 years at Secondary School "Chernorizets Hrabar" in the town of Plovdiv. The testing (chronometry) and mathematical-statistical methods (variation analysis and one-factor dispersion analysis - f-criterion of Fisher) are methods were used in our study. The analysis of speed and endurance tests (running at $30 \mathrm{~m}$. and $200 \mathrm{~m}$.) showed that the values were close and the tested classes were homogeneous - the coefficient of variation ranged from 7,59\% to 11,06\%. However, it is noteworthy that in the other tests, the coefficient of variation is greater, indicating that the groups are approximately homogeneous. In the age aspect, the results follow their logical tendency towards improvement, which for most groups is statistically significant. The least improve of the results is observed in the agility test. The difference in values is very small and not statistically significant. This gives us reason to propose an example methodology to improve spatial orientation and coordination as components of agility. It will include gymnastic movements, moveable games and naturallyapplied exercises.
\end{abstract}

Key words: physical capability, pupils, testing

\section{INTRODUCTION}

This article presents data from a national scientific project of the National Sports Academy "V. Levs$\mathrm{ki}$ "and the Ministry of Education and Science to study the physical capability of students from secondary schools in the Republic of Bulgaria.

In the theory of physical education the different sides of motor abilities are defined as motor qualities - speed, strength, endurance, flexibility, and agility (Rachev, K. et al., 2006; Jeliazkov, Ts., Dasheva, D., 2017). The development of these qualities and their dynamics through the years of children's growth are subject to numerous surveys, which, however, are partial or serve private purposes (Lazarova, K., 2006; Naydenova, K., 2014; Naydenova, K., Alachev, S., 2019; Petkov, K., 2017).

The tests for evaluation of motor qualities and the indicators of physical development are the basis for control of children's health condition (Borukova, M., Encheva, M., Stoychev, D., 2017; Lazarova, K., Tsvetkova, N., 2007).
According to a number of authors (Petkova, L., Kvartirnikova, M., 1985; Slanchev, P., 1992) the contemporary generation's way of life is characterized with reduced motor activity, lower physical ability, and as a whole, worse health condition.

The research in the field of physical education and sport in Bulgarian schools finds out that motor activity in classes does not correspond to the needs of rising generation, which imposes the necessity of additional physical activity through other forms of physical exercises and sport (Bankov, P., 2007; Peneva, B., 2002; Tosheva, I., 2002; Staikova, V., 2007; Petrova, M., 2005; Tarnichkova, M., et al., 2009).

Andonov, K. (2019) has optimized gymnastics curricula by paying special attention to the development of the qualities speed, endurance, and speedstrength qualities. These are the qualities which, in his opinion, ensure the better acquisition of the educational material. The author has introduced methods with an increased number of gymnastics exercises which undoubtedly leads to an increase in these qualities. 
Aim and objectives of the study

Our aim is to establish the initial level of physical qualities of pupils at primary schools. In order to achieve the aim, we set the following tasks:

1. To conduct a testing of the pupils at primary schools.

2. To process and analyze the obtained results.

3. To create exemplary methods for improvement of the testing results.

\section{METHODS}

The research was done in October 2018 at Secondary School "Chernorizets Hrabur" in the town of Plovdiv. The research was done among 83 pupils from $1^{\text {st }}$ to $4^{\text {th }}$ grade, aged between 7 and 10 years. We used a testing battery which bears information about the main indicators of physical ability. The battery includes five tests - running $30 \mathrm{~m}$, standing long jump, medicine ball throwing (1 kg), running $200 m$ (shuttle running), agility and spatial coordination test (Miladinov, et al., 2019).

The first four tests are standard and are applied in physical education and sport classes. The only new test is that for agility and spatial coordination. The pupils participated voluntarily in the research and were instructed before performing each test.

We used the following methods in our research: sports-pedagogical testing and math-statistical methods: variation analysis and one-factor dispersion analysis - $\mathrm{f}$-criterion of Fisher. The results from the research were processed with SPSS-19.0. (Gigova, 1999, 2002; Gigova, Damianova, 012).

\section{RESULTS}

The results from the variation analysis along all indicators of physical ability showed that the values had a normal distribution as regards asymmetry (As) and excess (Ex).

The researched classes showed there were not big variations from the mean value in the test "Running $30 \mathrm{~m}$ " which means that the groups were very homogeneous - the coefficient of variation ranged between $7.59 \%$ and $11.06 \%$ (Table 1).

The same was observed in the second and fourth grades in the test "Running $200 \mathrm{~m}$ " - V $=8.9 \%$ and $9.91 \%$. In all the other tests the homogeneity of the groups was relatively homogeneous, and the coefficient of variation was over $12 \%$.

Table 1. Variation analysis of the researched indicators of physical ability

\begin{tabular}{|c|c|c|c|c|c|c|c|}
\hline Indexes & Grade & $\mathbf{N}$ & $\mathbf{X}$ & $\mathbf{S}$ & Min & Max & $\mathbf{V}$ \\
\hline \multirow{4}{*}{ Running $30 \mathrm{~m}$} & 1 -st & 18 & 6,88 & 0,52 & 7,89 & 5,76 & 7,59 \\
\hline & 2-nd & 20 & 6,53 & 0,51 & 8,11 & 5,86 & 7,90 \\
\hline & 3-rd & 20 & 6,25 & 0,69 & 7,81 & 4,68 & 11,06 \\
\hline & 4-th & 25 & 6,10 & 0,47 & 7,18 & 5,36 & 7,85 \\
\hline \multirow{4}{*}{ Running $200 \mathrm{~m}$} & 1 -st & 18 & 59,89 & 7,62 & 80,79 & 48,88 & 12,73 \\
\hline & 2-nd & 20 & 55,94 & 4,97 & 66,33 & 48,39 & 8,90 \\
\hline & 3-rd & 20 & 53,29 & 6,61 & 70,35 & 43,53 & 12,41 \\
\hline & 4-th & 25 & 51,03 & 5,05 & 63,1 & 44,44 & 9,91 \\
\hline \multirow{4}{*}{ Standing Long jump } & 1 -st & 18 & 112,5 & 13,18 & 86 & 134 & 11,72 \\
\hline & 2-nd & 20 & 114,25 & 19,17 & 79 & 143 & 16,79 \\
\hline & 3-rd & 20 & 119,85 & 23,20 & 73 & 158 & 19,36 \\
\hline & 4-th & 25 & 138,16 & 18,14 & 100 & 170 & 13,14 \\
\hline \multirow{4}{*}{ Medicine ball throwing } & 1 -st & 18 & 313,66 & 68,23 & 213 & 446 & 21,75 \\
\hline & 2-nd & 20 & 301,45 & 85,39 & 167 & 459 & 28,33 \\
\hline & 3-rd & 20 & 346,9 & 88,17 & 210 & 590 & 25,42 \\
\hline & 4-th & 25 & 479,24 & 106,62 & 292 & 689 & 22,25 \\
\hline \multirow{4}{*}{ Agility test } & $1-\mathrm{st}$ & 18 & 20,63 & 2,78 & 27,63 & 17,96 & 13,51 \\
\hline & 2-nd & 20 & 19,38 & 3,32 & 29,93 & 15,89 & 17,14 \\
\hline & 3-rd & 20 & 20,00 & 3,17 & 27,15 & 16,15 & 15,88 \\
\hline & 4-th & 25 & 18,28 & 2,23 & 22,06 & 14,74 & 12,20 \\
\hline
\end{tabular}

It is known that due to the representativeness of of the statistical hypotheses are probable (Gigothe samples, the decisions to be taken in the check va, 1999). The acceptance or rejection of the zero 
hypothesis is made at certain security level and at the same time the possibility of making a statistical mistake is considered.

In order to check the zero hypothesis about the significance of the observed differences between the average levels of the researched indicators in the different samples (83 pupils from $1^{\text {st }}$ to $4^{\text {th }}$ grade, aged from 7 to 10 years), we used one-factor dispersion analysis. We calculated F-criterion of Fisher at a high level of statistical reliability ( $\mathrm{Pt} \geq 95 \%$ ). The results from the comparison allow us to make conclusions about the degree of influence of a certain factor (manifested in nominal or ordinal scale)
- each group in our case, on the researched indicators. The first step in one-factor analysis is related to determining the number and character of the so-called inter-group and among group dispersions along each indicator at the same levels of freedom, respectively к $1=\mathrm{m}-1$ (where $\mathrm{m}$ is the number of the compared samples) and $\mathrm{\kappa} 2=\mathrm{n}-\mathrm{m}$, on which basis the values of F-criterion of Fisher and their corresponding levels of significance $\alpha$ and $P(F)$ are calculated.

Table 2 presents the dispersion criteria obtained from the comparison of the researched indicators.

Table 2. Dispersion criteria $($ Ftabl $=2,78)$

\begin{tabular}{|l|l|l|l|l|}
\hline № & \multicolumn{1}{|c|}{ Indexes } & $\mathbf{F}_{(\text {emp) }}$ & \multicolumn{1}{|c|}{ Sig. } & \multicolumn{1}{|c|}{$\mathbf{P}_{(\mathbf{F})}$} \\
\hline 1. & Running 30 m & 7,646 & 0 & 100,00 \\
\hline 2. & Running 200 m & $\mathbf{8 , 1 0 0}$ & 0 & 100,00 \\
\hline 3. & Standing Long jump & $\mathbf{8 , 8 4 6}$ & 0 & 100,00 \\
\hline 4. & 1 kg medicine ball throwing & $\mathbf{1 8 , 9 7 7}$ & 0 & 100,00 \\
\hline 5. & Agility test & 2,629 & 0,056 & 94,44 \\
\hline
\end{tabular}

The analysis of the table shows that the calculated values of F-criterion of Fisher $\left(\mathrm{F}_{\mathrm{emp}}\right)$ in most of the indicators were higher than the critical value $\left(\mathrm{F}_{\text {tabl }}\right.$ $=2.78$ ). This allows us, with high guarantee probability, to reject the zero hypothesis and to accept the alternative hypothesis according to which the observed differences among the mean levels of four of the researched indexes for the different classes are significant. This fact is confirmed by the level of significance $\alpha$, which took values below 0.05 . Only as regards indicator 5 "Agility" there were no statistically significant differences among different classes. In order to determine the exact differences among different samples, we used the second step of dispersion analysis, which is related to calculation of the so-called Tukey`s Honestly Significant Difference. This allowed us to compare each pair of samples along the principle "each against each". The number of the possible combinations for each indicator is determined with the formula: $A=n(n-1) / 2$. The number of the compared samples is 4 , therefore the possible combinations here are 6.

The results from the comparison of the indicators, which confirm the alternative hypothesis, are presented in special matrixes, where the rejection of the zero hypothesis is presented with a star $\left(_{*}\right)$.

Table 3. Differences among the researched classes' mean values of indicators

\begin{tabular}{|c|c|c|c|c|c|c|c|c|c|c|c|c|c|c|c|c|c|c|c|c|c|}
\hline & \multicolumn{3}{|c|}{$\begin{array}{c}\text { 1-st test } \\
\text { running 30 m }\end{array}$} & \multicolumn{3}{c|}{$\begin{array}{c}\text { 2-nd test } \\
\text { running 200 m }\end{array}$} & \multicolumn{4}{c|}{$\begin{array}{c}\text { 3-rd test } \\
\text { long jump }\end{array}$} & \multicolumn{3}{c|}{$\begin{array}{c}\text { 4-th test } \\
\text { ball throwing (1 kg.) }\end{array}$} & \multicolumn{5}{c|}{$\begin{array}{c}\text { 5-th test } \\
\text { agility test }\end{array}$} \\
\hline grade & 1-st & 2-nd & 3-rd & 4-th & 1-st & 2-nd & 3-rd & 4-th & 1-st & 2-nd & 3-rd & 4-th & 1-st & 2-nd & 3-rd & 4-th & 1-st & 2-nd & 3-rd & 4-th \\
\hline 1-st & & & $*$ & $*$ & & & $*$ & $*$ & & & & $*$ & & & & $*$ & & & & $*$ \\
\hline 2-nd & & & & & & & & $*$ & & & & $*$ & & & & $*$ & & & & \\
\hline 3-rd & $*$ & & & & $*$ & & & & & & & $*$ & & & & $*$ & & & & \\
\hline 4-th & $*$ & & & & $*$ & $*$ & & & $*$ & $*$ & $*$ & & $*$ & $*$ & $*$ & & $*$ & & & \\
\hline
\end{tabular}

\section{DISCUSSION}

Table 3 presents the existing differences among the mean values of indicator "Running $30 \mathrm{~m}$ " of the pupils from the researched classes. We can see that there was a statistically significant difference in the results between $1^{\text {st }}$ and $3^{\text {rd }}$ grade, as well as between $1^{\text {st }}$ and $4^{\text {th }}$ grade. Nevertheless, there is a positive change in the mean values every year (Figure 1), 
which shows that the speed of the pupils is improv- ing.

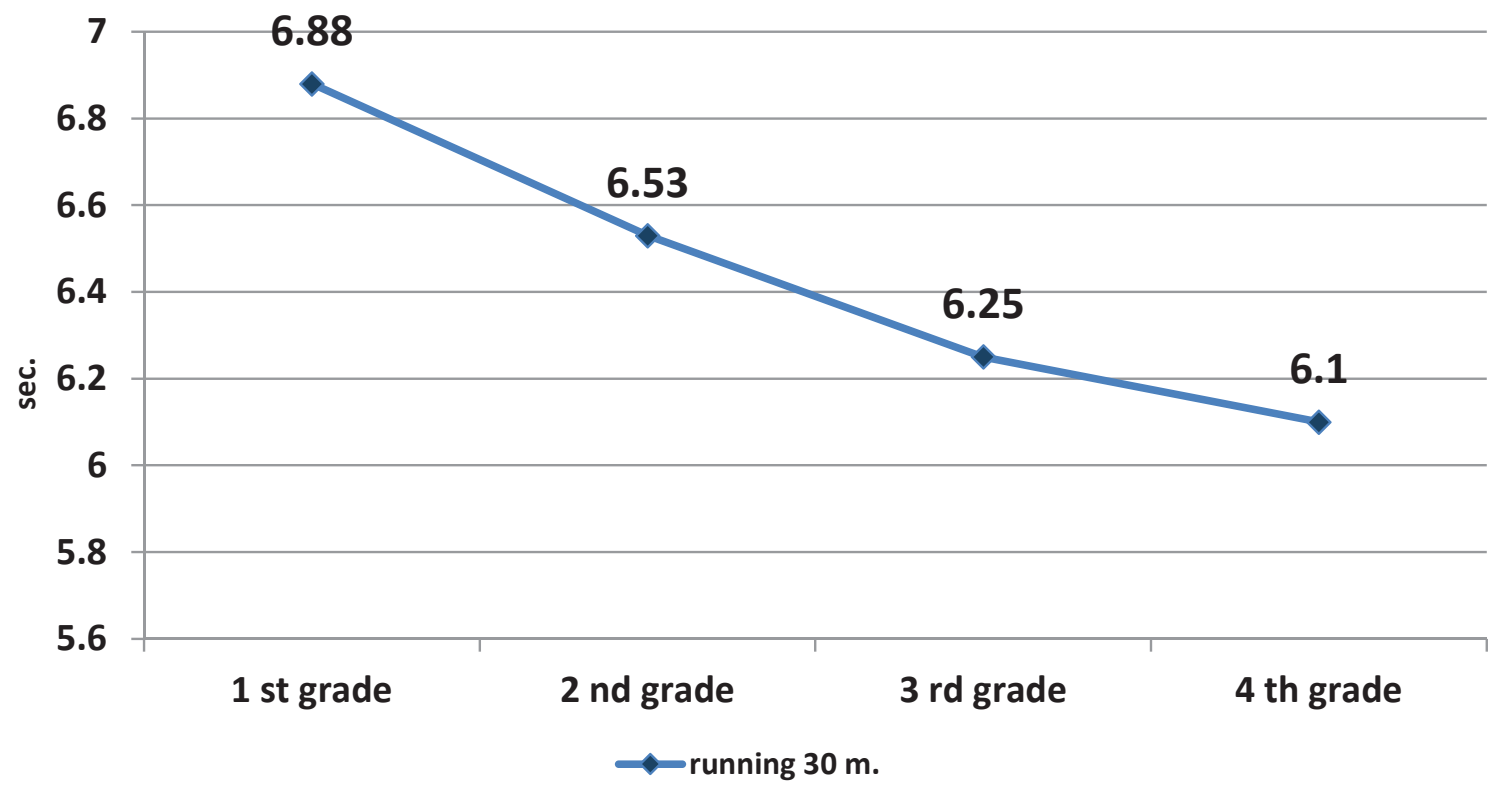

Figure 1. Dynamics of development of the "Running $30 \mathrm{~m}$." indicator

In the second test "Shuttle run $200 \mathrm{~m}$ " the mean liable only between some of the grades (Table 3 ). values decreased, which shows a significant im- There is a statistically significant difference between provement in the results of every subsequent grade $1^{\text {st }}$ and $3^{\text {rd }}$ grade, $1^{\text {st }}$ and $4^{\text {th }}$ grade, and $2^{\text {nd }}$ and $4^{\text {th }}$ (Figure 2). grade. The growth in the mean values between $1^{\text {st }}$ and $2^{\text {nd }}$ grade, as well as between $2^{\text {nd }}$ and $3^{\text {rd }}$ grade is

This improvement in the results is statistically re- accidental and is not statistically reliable.

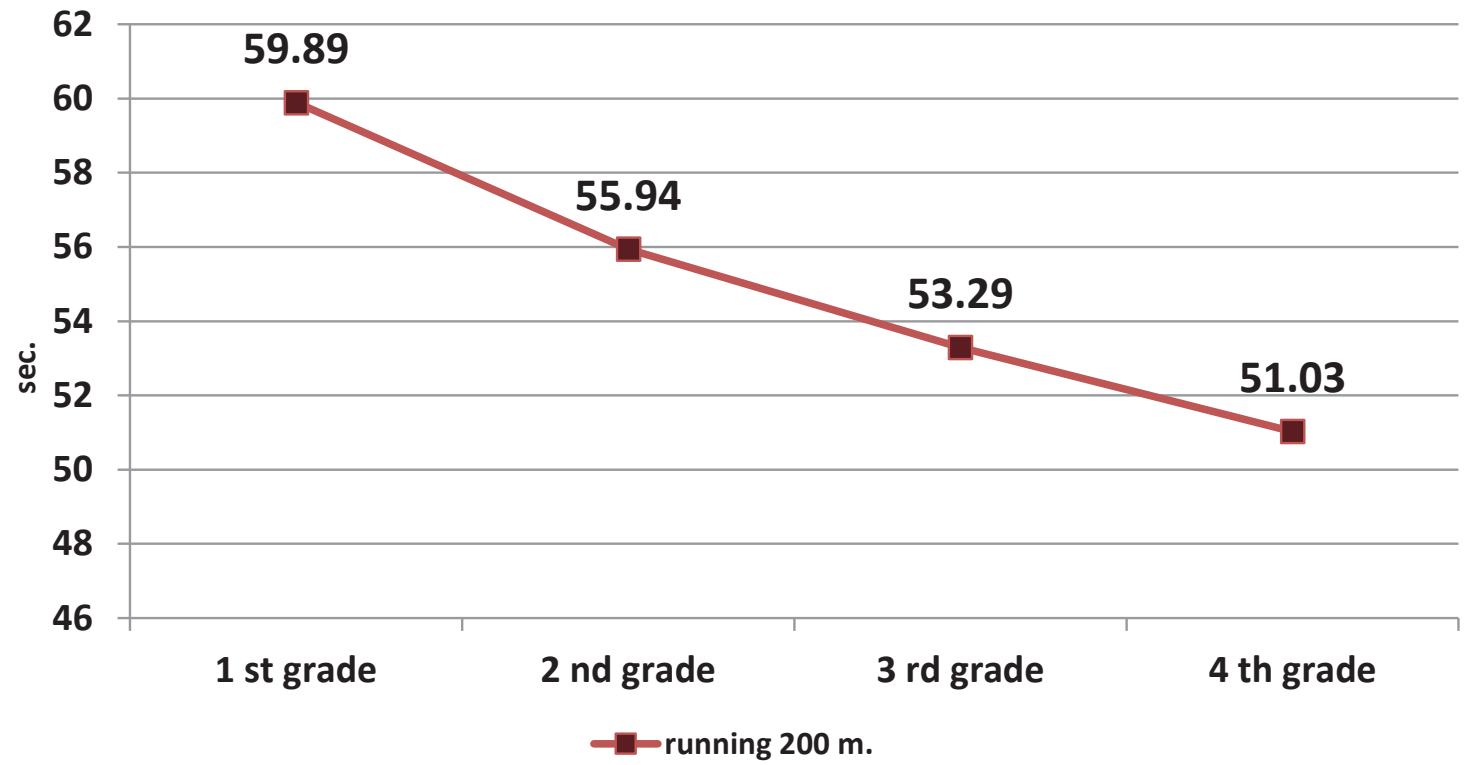

Figure 2. Dynamics of development of the "Running $200 \mathrm{~m}$." indicator

The next test is "Standing long jump". We used it to not statistically significant. We believe that this fact trace the development of the explosive power of the may be due to the more complex technique in the lower limbs in horizontal efforts. Figure 3 presents execution of the exercise which was not learnt well. the dynamics of the mean values of the researched However, the bigger difference of $18.31 \mathrm{~cm}$ between indicator. We can see that the values increase grad- $3^{\text {rd }}$ and $4^{\text {th }}$ grade should be pointed out and it is staually from $1^{\text {st }}$ to $3^{\text {rd }}$ grade, but the differences are tistically significant. There are statistically signifi- 
cant differences between $1^{\text {st }}$ and $4^{\text {th }}$ grade and $2^{\text {nd }}$ and $4^{\text {th }}$ grade (Table 3$)$.

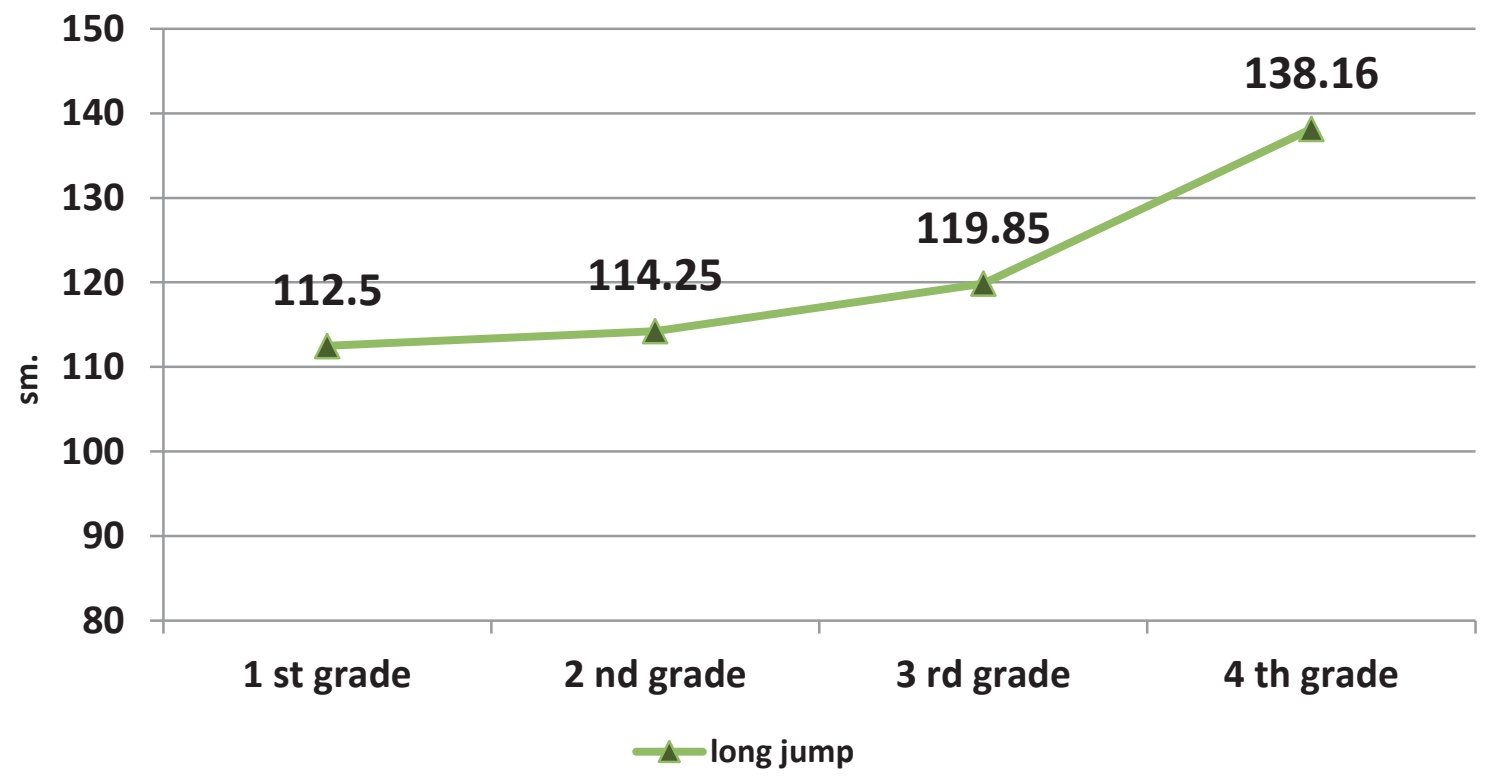

Figure 3. Dynamics of development of the "Standing Long jump" indicator

Table 3 presents the differences in the mean values crease in the mean value between $3^{\text {rd }}$ and $4^{\text {th }}$ grade of the indicator "Medicine ball throwing 1m". Their is the most significant $-132.34 \mathrm{~cm}$.

statistical reliability is the same as in the test "Long In this test we can observe a decrease in the mean jump". There is a statistically significant difference value from $1^{\text {st }}$ to $2^{\text {nd }}$ grade, which might be due between $1^{\text {st }}$ and $4^{\text {th }}$ grade, $2^{\text {nd }}$ and $4^{\text {th }}$ grade, and $3^{\text {rd }}$ to accidental circumstances (poor technique of and $4^{\text {th }}$ grade.

throwing, weaker explosive power of upper limbs, There was a growth of $45.45 \mathrm{~cm}$ between $2^{\text {nd }}$ and lack of motivation for showing maximum perfor$3^{\text {rd }}$ grade but it is not significant (Figure 4 ). The in- mance, etc.).

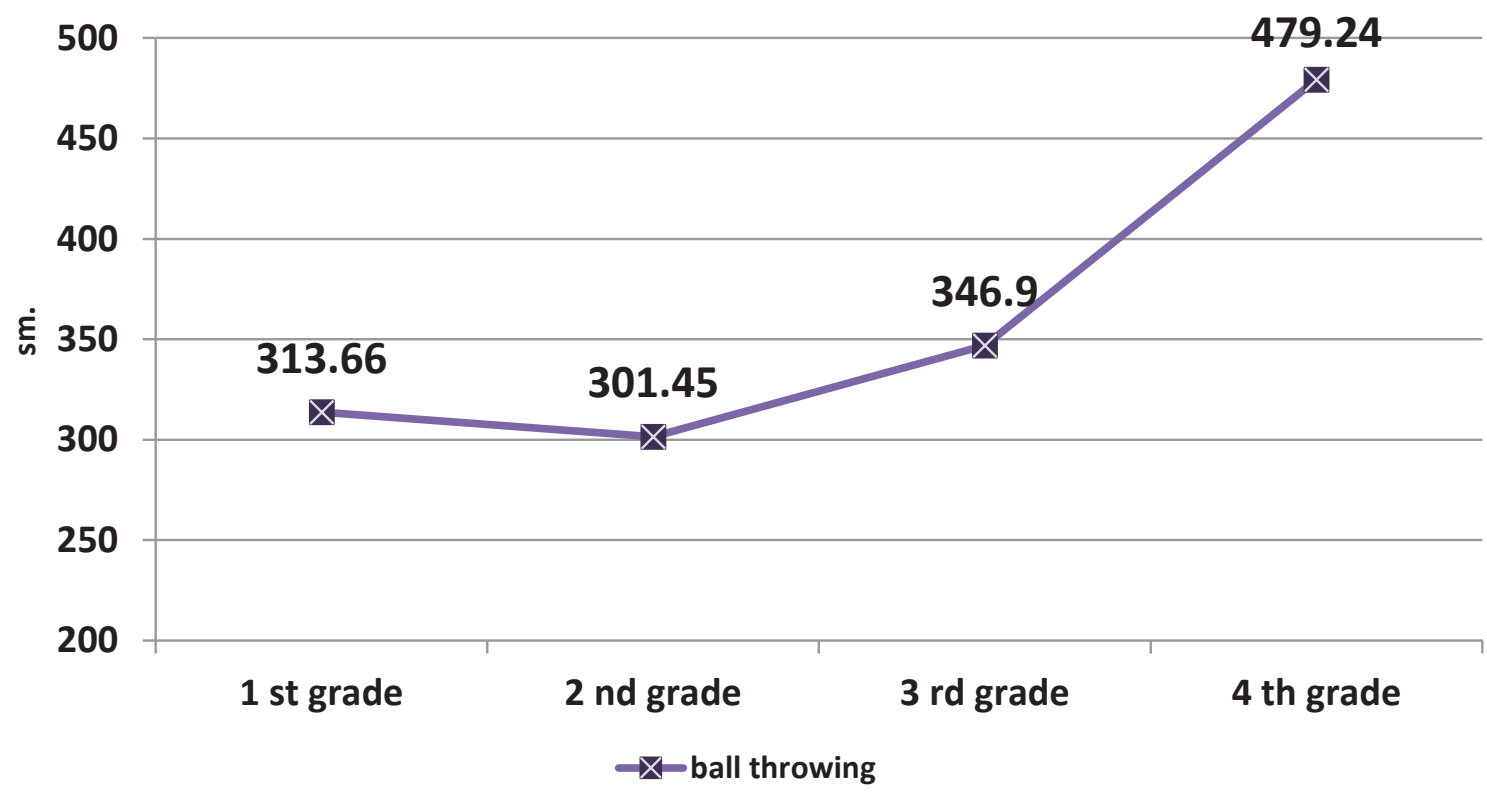

Figure 4. Dynamics of development of the "Ball throwing (1 kg.)" indicator

The last test assesses pupils' agility and includes carry four small balls one after the other and place movements for coordination and spatial orienta- them in a target by running in a T-shape (Figure 5). tion, object agility and precision. The pupils had to All motor actions in the test should be performed 
with maximal speed which set requirements to the opinion, to the test "Running 30m" and "Shuttle development of velocity and corresponded, in our running $200 \mathrm{~m}$ ".

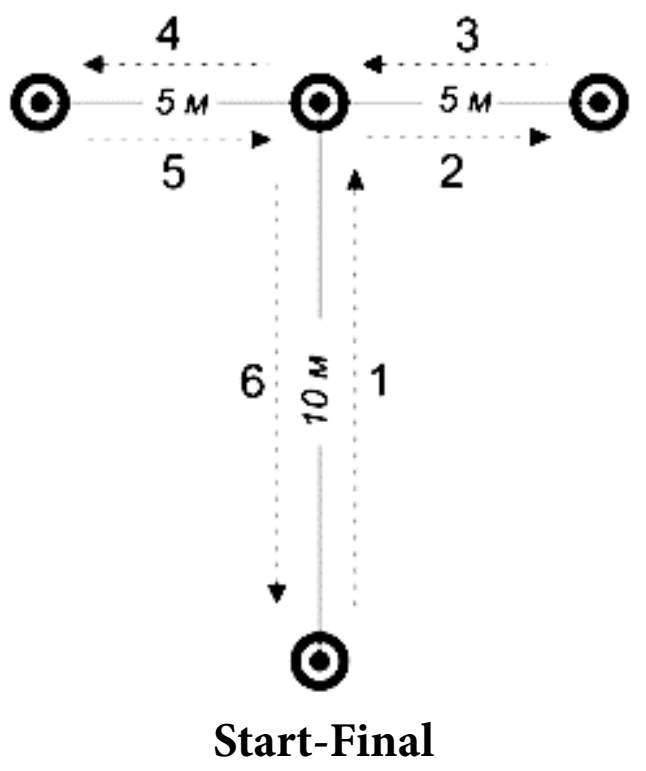

Figure 5. Agility test

Tracing the dynamics of the development of the The small difference between $1^{\text {st }}$ and $2^{\text {nd }}$, as well as $1^{\text {st }}$ and $4^{\text {th }}$ - grade pupils' agility, we found out that $3^{\text {rd }}$ and $4^{\text {th }}$ grade is statistically unreliable. The worse the results, as a whole, improved slightly (Figure 6). results of the 3-grade pupils should be taken into There is a statistically significant difference only beconsideration. tween $1^{\text {st }}$ and $4^{\text {th }}$ grade (table 7 ), and it is $2.35 \mathrm{sec}$.

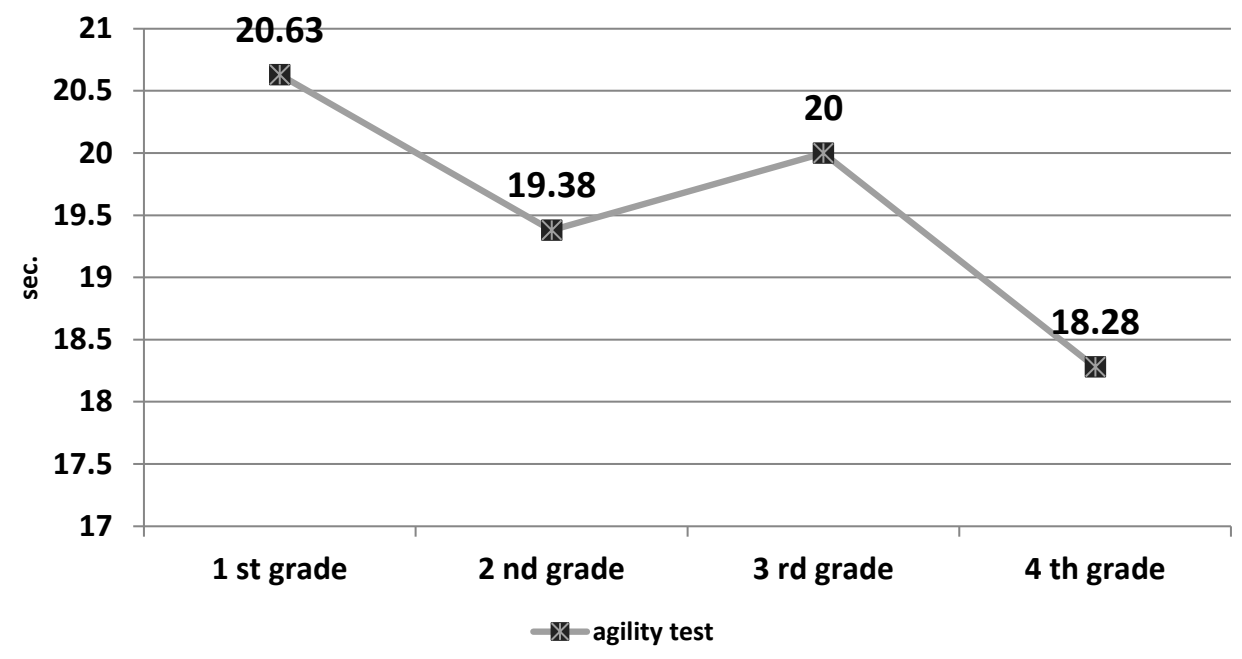

Figure 6. Dynamics of development of the "Agility test" indicator

In conclusion we can sum up that in the four tests, Having in mind that the sensitive periods of the which require easier motor actions such as running development of coordination abilities is between 7 and jumping, pupils' results from $1^{\text {st }}$ to $4^{\text {th }}$ grade im- and 12 years and through adolescence, as well as prove logically. The results, however, do not follow the achieved poorer results from the agility test, we this progression for the other two tests ("Medicine can introduce some exemplary gymnastics exercisball throwing" and "Agility test"). We believe that es for improvement of spatial orientation and coorthis is due to the more complex structure of the dination (moving in straddle position and moving movements and the necessity of additional teach- in straddle pike position; rolls, passing through a ing before their execution. hoop, jumping, jumping over, and carrying). 
We suggest that these exercises should be learnt performed in competitive games so that pupils' well in the physical education classes before being physical fitness be improved (Table 4).

Table 4. Exemplary games to improve physical fitness

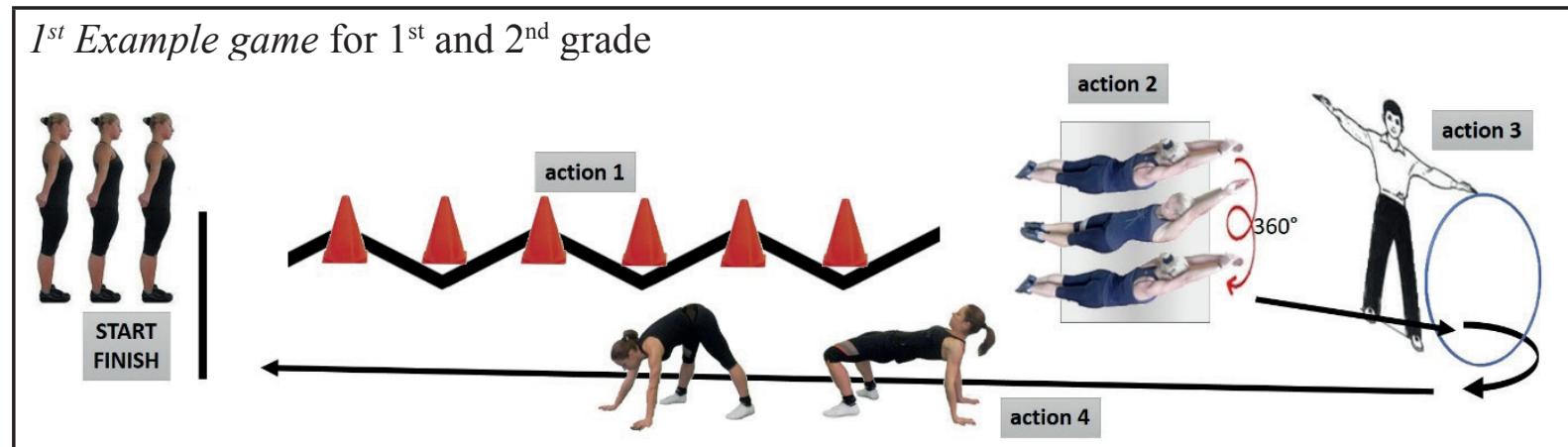

actions: 1-running on zig-zag; 2- rolling around the longitudinal axis; 3- passing through the hoop; 4-moving in straddle pike position or straddle back support; final

$1^{\text {st }}$ Example game for $3^{\text {rd }}$ and $4^{\text {th }}$ grade
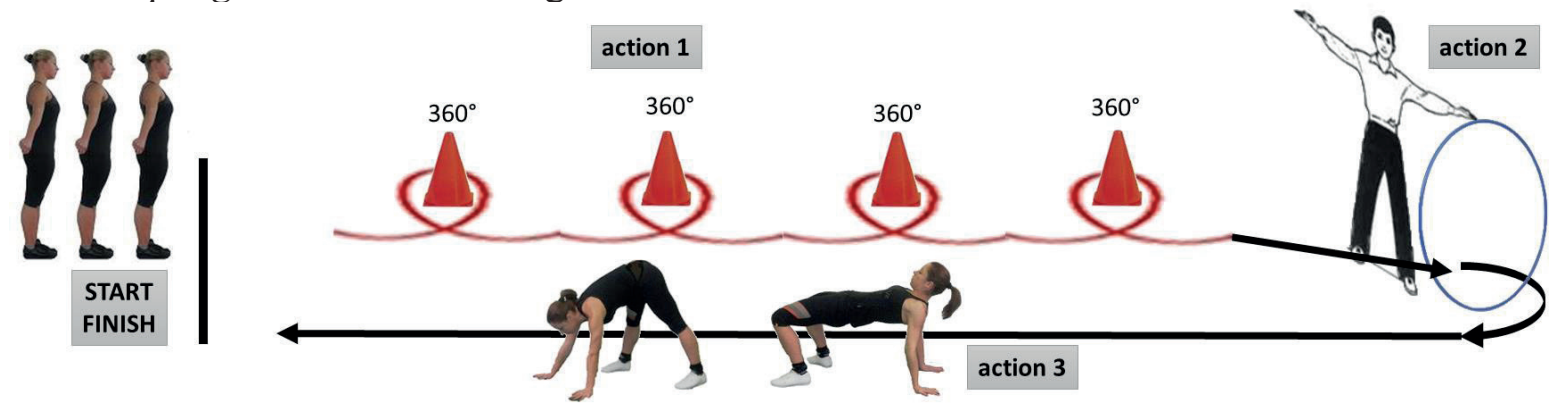

actions: 1-running with the circumference of each cone; 2-passing through the hoop; 3- moving in straddle pike position or straddle back support; final

$2^{\text {nd }}$ Example game for $1^{\text {st }}$ and $2^{\text {nd }}$ grade
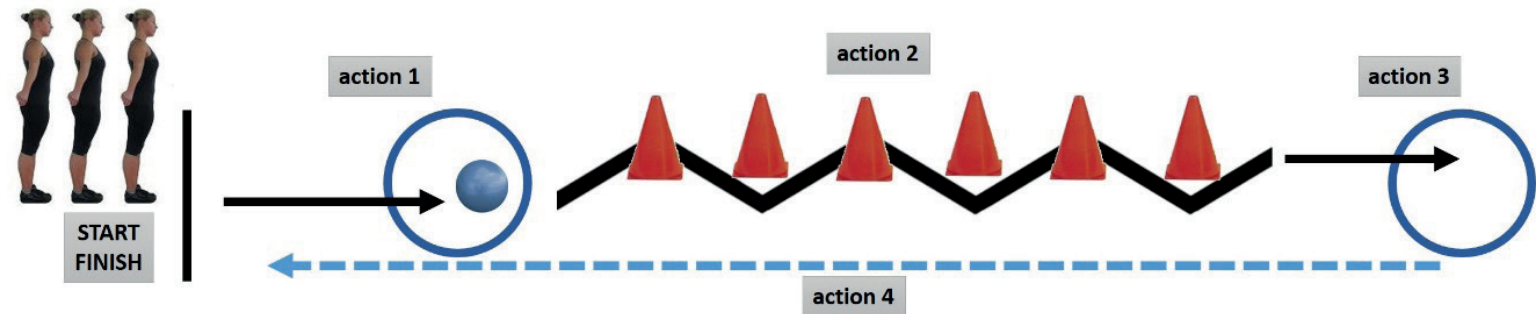

actions: 1- running to the hoop and taking the ball; 2- running on zig zag; 3-placing the ball in the hoop; 4-running; final ( the next player returns the ball to the first hoop)

$2^{\text {nd }}$ Example game for $3^{\text {rd }}$ and $4^{\text {th }}$ grade

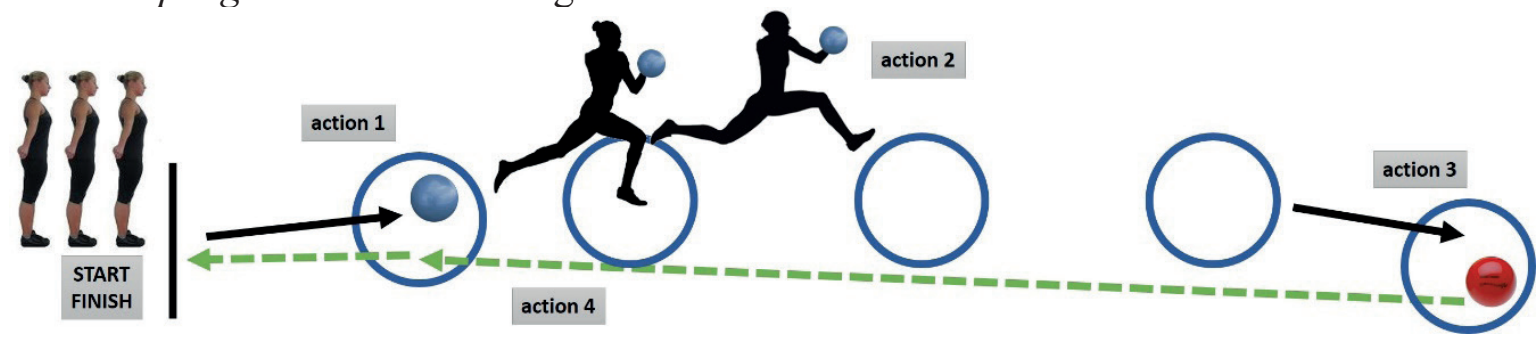

actions: 1-running to the hoop and taking the ball; 2-multiple jumps through the hoops; 3-placing the ball in the hoop and take the other; 4-running, placing the ball in the first hoop; final 


\section{REFERENCES}

Andonov, K. (2019). Optimizirane na uchebnite programi po gimnastika $v$ uchilishtnoto fizichesko vazpitanie pri uchenitsi ot purvi do shesti klas, NSA PRES, Sofia.

Bankov, P. (2007). Upravlenie na sporta $v$ svobodnoto vreme, B-INS, Sofia.

Borukova, M., Encheva, M., Stoychev, D. (2017). Sravnitelen analiz na fizicheskoto razvitie i deesposobnost na uchenichki, Mezhdunarodna nauchna konferentsia, Aktualni problemi na fizicheskata kultura, 2017, NSA PRES, Sofia, pp.121-126.

Gigova, V. (1999). Statisticheska obrabotka i amaliz na danni, Uchebno pomagalo za studentite ot magistarska stepen na NSA, Sofia

Gigova, V. (2002). Statisticheska obrabotka i amaliz na danni, NSA-IPB, Sofia.

Gigova. V., Damianova, R. (2012). Statisticheski metodi v sporta, NSA PRES, Sofia.

Jeliazkov, Ts., Dasheva. D. (2017). Osnovi na sportnata trenirovka, B-INS, Sofia.

Lazarova, K. (2006). Razvitie na dvigatelnite kachestva na uchenitsi - momcheta - ot peti klas za ednogodishten period na zanimaniya po fizichesko vazpitanie, 4-ta Natsionalna konferentsia, Dokladi i saobshtenia, 26-29 april, Varna, Pikadili, Varna, pp. 215.

Lazarova, K., Tsvetkova, N. (2007). Vazmozhnost za otsenyavane na dvigatelnite kachestva na uchenitsite $\mathrm{v}$ protsesa na obuchenie po fizichesko vazpitanie i sport, Sport \& Nauka, Izv.br.1, Sofia, pp. 271.

Miladinov, O. et al. (2019). Sistema za otsenyavane na fizicheskata deesposobnost na uchenitsite ot I-vi do XII-ti klas, NSA PRES, Sofia.

Naydenova, K. (2014). Proverka nadezhdnostta na testove za otsenka na skorostnite kachestva na 9-10-godishni uchenitsi, Sport \& Nauka, N 6, Sofiya, pp.92-99.

Naydenova, K., Alachev, S. (2019). Promeni v stoynostite na skorrostno-silovite vazmozhnosti na uchenichki ot gimnazialen etap, ustanoveni chrez testa "Skok na dalzhina s dva kraka ot myasto", Sport \& Nauka, N 1,2, Sofiya, pp.90-97.
Peneva, B. (2002) Aktualni problem na sadarjanieto I metodikata na uchilishtoto fizichesko vazpitanie, Mejdunarodna nauchna konferencia, "Kineziologia 2002", Veliko Tarnovo, Boika, Veliko Tarnovo, pp.19-22.

Petkov, K. (2017). Izmenenie na fizicheskata deesposobnost pri uchenitsi vav vazrastov aspekt-11-13 godini, Mezhdunarodna nauchna konferentsia, Aktualni problemi na fizicheskata kultura, 2017, NSA PRES, Sofia, pp.100-104.

Petkova, L., Kvartirnikova, M. (1985). Testove za ozenjavane na fizicheskata deesposobnost, Medicina \& Fizkultura, Sofia.

Petrova, M. (2005). Prouchvane sastoiynieto na fizicheska deesposobnost na momicheta ot nachalna uchilishtna vazrast, zanimavashti se s gimnastika $v$ izvanurochna forma, Sport \& Nauka, izv. broi 2, Sofia.

Rachev, K., et al. (2006). Obshti osnovi na teoriya i metodika na fizicheskoto vazpitanie, chast I, 4-to preraboteno izdanie, NSA PRES, Sofia.

Slanchev, P. (1992). Sportna medicina, Uchebnik za studenti ot NSA, Medicina \& fizkultura, Sofia.

Staykova, V. (2007). Fezicheska deesposobnost I samoocenka na uchashtite se, Sport \& Nauka, № 1, Sofia, pp. 283-289.

Tarnichkova, M., Ilieva, S., Tankusheva, N., Yanev, Il., Gateva, M. (2009). Fizicheska deesposobnost na detsa zanimavashti se s razlichni gimnasticheski distsiplini. Mezdunarodna nauchna konferentsia, "Kineziologia 2009", Veliko Tarnovo, Boika, Veliko Tarnovo,

Tosheva, I. (2002). Dvete litsa na fizicheskoto vazpitanie, Mezdunarodna nauchna konferentsia, „Kineziologia 2002“, Veliko Tarnovo, Boika, Veliko Tarnovo, pp.67-68.

\section{Corresponding autor:} Marina Petrova, Milena Tarnichkova

National Sports Academy "V. Levski" Department of Gymnastics Studentski grad, 1700 Sofia, Bulgaria E-mail: maripet@abv.bg; milenansa@abv.bg 